\title{
Subsidence of organic dredged sediments in an upland deposit in Wormer- en Jisperveld: North Holland, the Netherlands
}

\author{
Bruna R. F. Oliveira ${ }^{1} \mathbb{D}$ - Martijn P. J. Smit ${ }^{1} \cdot$ Harry Veld $^{2} \cdot$ Leon A. van Paassen ${ }^{3} \cdot$ Huub H. M. Rijnaarts ${ }^{1}$. \\ Tim Grotenhuis ${ }^{1}$
}

Received: 8 August 2017 / Accepted: 20 January 2018 / Published online: 13 February 2018

(c) The Author(s) 2018. This article is an open access publication

\begin{abstract}
Land subsidence in low-lying peatlands can be caused by shrinkage and organic matter oxidation. When these areas have networks of ditches and canals for drainage purposes, the sediments that accumulate in the waterways can be used to reverse the process of land subsidence. The objective of this study is to understand how dredged sediments can be used to reverse the process of land subsidence by analysing the contribution of shrinkage and organic matter mineralization to the subsidence observed in an upland deposit. A deposit of dredged sediments in the Wormer- en Jisperveld — North Holland, the Netherlands-was characterized during 17 months in terms of subsidence of the sediments, subsidence of the soil underlying the deposit, geotechnical water content, organic matter content, type of organic matter and nutrients. The deposit was filled to a height of $195 \mathrm{~cm}$, and after 17 months, the subsidence of the sediments was $88 \mathrm{~cm}$. In addition, a subsidence of $19.5 \mathrm{~cm}$ of the underlying soil was observed. Subsidence could be attributed to shrinkage since no significant changes in the organic matter content and total organic carbon were observed. The type of organic matter changed in the direction of humification until winter 2014, stabilized from winter 2014 to spring 2015 and changed in the direction of mineralization after the spring of 2015. Subsidence of dredged sediments in upland deposits is caused by shrinkage during the first 17 months. The solution of spreading thinner layers of sediments over the land to decrease the subsidence rates should be explored since the pressure of the deposit on the underlying soil caused an extra subsidence of $19.5 \mathrm{~cm}$.
\end{abstract}

Keywords Dredged sediments $\cdot$ Upland deposit $\cdot$ Subsidence $\cdot$ Shrinkage $\cdot$ Organic matter oxidation $\cdot$ Lowlands $\cdot$ Peatlands

\section{Introduction}

The Wormer-en Jisperveld is the largest contiguous peatland in the Netherlands and due to land subsidence and sea level rise, the water level in this peatland was $1.54-1.58 \mathrm{~m}$ below sea in 2011 (Linders 2011).

Land subsidence in peatlands is a consequence of drainage that results in shrinkage due to the loss of volume

Bruna R. F. Oliveira

bruna.oliveira@ua.pt

Tim Grotenhuis

Tim.Grotenhuis@wur.nl

1 Environmental Technology, Wageningen University and Research Centre, Wageningen, The Netherlands

2 Deltares, Utrecht, The Netherlands

3 Faculty of Civil Engineering and Geosciences, Delft University of Technology, Deft, The Netherlands occupied by the water and rearrangement of the particles when the water is removed (Oleszczuk et al. 2003), and organic matter oxidation (Sanei et al. 2005). The oxidation of the organic matter can result in humification or mineralization. Humification is the transformation of organic matter into amorphous humic compounds, and mineralization refers to the transformation of organically bound elements $(\mathrm{C}, \mathrm{N}$, P, S) into inorganic compounds (Zech et al. 1997).

In these low-lying peatlands, it is necessary to lower the water level especially to maintain the necessary conditions for agriculture and to avoid flooding. For that, dense networks of watercourses and pumping stations are needed which is perpetuating the subsidence and is becoming increasingly costly (Querner et al. 2012).

In the Wormer-en Jisperveld area, the network of water courses has 2.3 million $\mathrm{m}^{3}$ of sediments that have to be dredged to preserve the area (Linders 2011). One of the current practices is to store the dredged sediments in upland deposits of 1-2 m height. Dredged sediments have 
approximately $70 \% \mathrm{~g}_{\text {water }} \mathrm{g}_{\text {sediment }}^{-1}$, and in the upland deposits, the sediments are dewatered through run-off (horizontal), drainage (vertical downwards) and evapotranspiration (vertical upwards). Simultaneously to dewatering, also sedimentation, consolidation and ripening occur, transforming the waterlogged sediments into an aerated soil. Sedimentation takes place within hours or days and refers to the settling of the particles. Consolidation is driven by the overburden pressure caused by the weight of the overlying layer. Ripening can be subdivided into physical, chemical and biological ripening. During the physical ripening dehydration and shrinkage occur, the permeability and consistency increase, and cracks are formed. The chemical ripening refers to the oxidation combined with chemical changes that occur due to the improved aeration. Biological ripening refers to the activity of soil fauna and flora (Vermeulen 2007). Dewatering and the overall ripening process are accelerated by crack development (Vermeulen et al. 2003) and evapotranspiration caused by plants (Oliveira et al. 2018, In Press).

Many other lowlands delta areas suffer from subsidence (Aich et al. 2013; Hooijer et al. 2012; Pronger et al. 2014; Querner et al. 2012; Wöppelmann et al. 2013), and sediments are a natural resource that can be beneficially used to reverse the process of land subsidence, especially considering that in some areas the sediments and water flow are restrained upstream which limits the natural restoration through sediment accumulation in delta areas (Kolker et al. 2011).

The objective of this study is to understand how dredged sediments can be used to reverse the process of land subsidence by analysing the contribution of shrinkage and organic matter mineralization to the subsidence observed in an upland deposit. For that, the deposit is characterized in terms of subsidence of the sediments and soil underlying the deposit, and arbitrary layers of $10 \mathrm{~cm}$ from surface to bottom are analysed in terms of geotechnical water content, organic matter content, type of organic matter and nutrients.

\section{Materials and methods}

\section{Site description}

Between 2001 and 2014, 2.3 million $\mathrm{m}^{3}$ of sediments were dredged from the waterways in the Wormer- and Jisperveld area. The dredged sediments were used to restore waterfronts, raise the surface level of some meadows and stored in upland deposits. In this research, the focus was on one of these upland deposits named Deposit X1 (52 $31^{\prime} 15.3^{\prime \prime} \mathrm{N}$ $\left.4^{\circ} 49^{\prime} 53.4^{\prime \prime} \mathrm{E}\right)$. Deposit X1 has approximately $145 \mathrm{~m}$ of length and $120 \mathrm{~m}$ width and was formerly used for grazing cattle. The typical lithology in the area is formed by peat from 0.0 to $0.3 \mathrm{~m}$ and from 0.4 to $3.0 \mathrm{~m}$, and clay from 0.3 to $0.4 \mathrm{~m}$ and from 3.0 to $3.5 \mathrm{~m}$ (www.dinoloket.nl/onder grondgegevens).

To prepare Deposit X1, approximately $30 \mathrm{~cm}$ of topsoil was removed and this topsoil was used to construct the dikes around the deposit. This resulted in the bottom of Deposit $\mathrm{X} 1$ being a mixture of peat and clay. The height from the bottom of the deposit to the top of the dikes was about $2.15 \mathrm{~m}$. The deposit was split into two compartments, A and $\mathrm{B}$, separated by a dike which reached a height of about $1.90 \mathrm{~m}$. The Deposit X1 was filled with sediments in two stages: the first stage was from 20/Jan/2014 to 30/Mar/2014, and the second stage was from $1 / \mathrm{Jul} / 2014$ to $16 /$ Oct/2014 The filling was done by the water board Hoogheemraadschap Hollands Noorderkwartier (HHNK) in two stages due to two main reasons: during the birds breeding season from $15 / \mathrm{Mar} / 2014$ to $15 / \mathrm{Jun} / 2014$, no works can be done; and during spring and summer, there is a significant reduction in the volume occupied by the sediments, and therefore, the deposit has space to allocate more sediments after the summer (information provided by the water board HHNK).

Two level gauges were placed in the deposit to monitor subsidence (Fig. 1). In addition, the water board HHNK monitored the subsidence of the bottom of the deposit by determining the level of the level gauges in relation to a geodetic reference level. At the southern side of the deposit, a wooden platform was installed in compartment A to allow sampling of the dredged sediments.

The Deposit X1 also had an adjustable wooden wall on the western side. After settling of the sediments, the wooden wall would be open to allow the horizontal run-off of the clear water to an adjacent ditch (horizontal run-off).

The average daily temperature and the daily precipitation recorded at the nearest weather station which is located in Wijk aan Zee are in Fig. 2 (KNMI 2016).

\section{Sampling}

Column samples of dredged sediments were taken (Table 1) using a gouge auger sampler with diameter of $25 \mathrm{~mm}$ (Eijkelkamp Soil \& Water). On each sampling day, three column samples were taken and each section analysed represents the mixture of the three columns. The thickness of the sediments in the deposit varies in time both by the filling of the deposit (increase) and by the sediment shrinkage after the filling stages (decrease). As upfront, during sampling of sediment cores, such shrinkage characteristics could not be quantified, and therefore, it was chosen to characterize each $10 \mathrm{~cm}$ layer from the top $(0 \mathrm{~cm})$ to a depth of $120 \mathrm{~cm}$ of the deposit. Results upon physical shrinkage and compaction within the deposit will be elaborated and discussed in a separate paper in preparation by van Paassen et al.

Sampling was always done from the "platform for sampling" (Fig. 3). The column samples were divided into 
Fig. 1 Schematic representation of Deposit X1

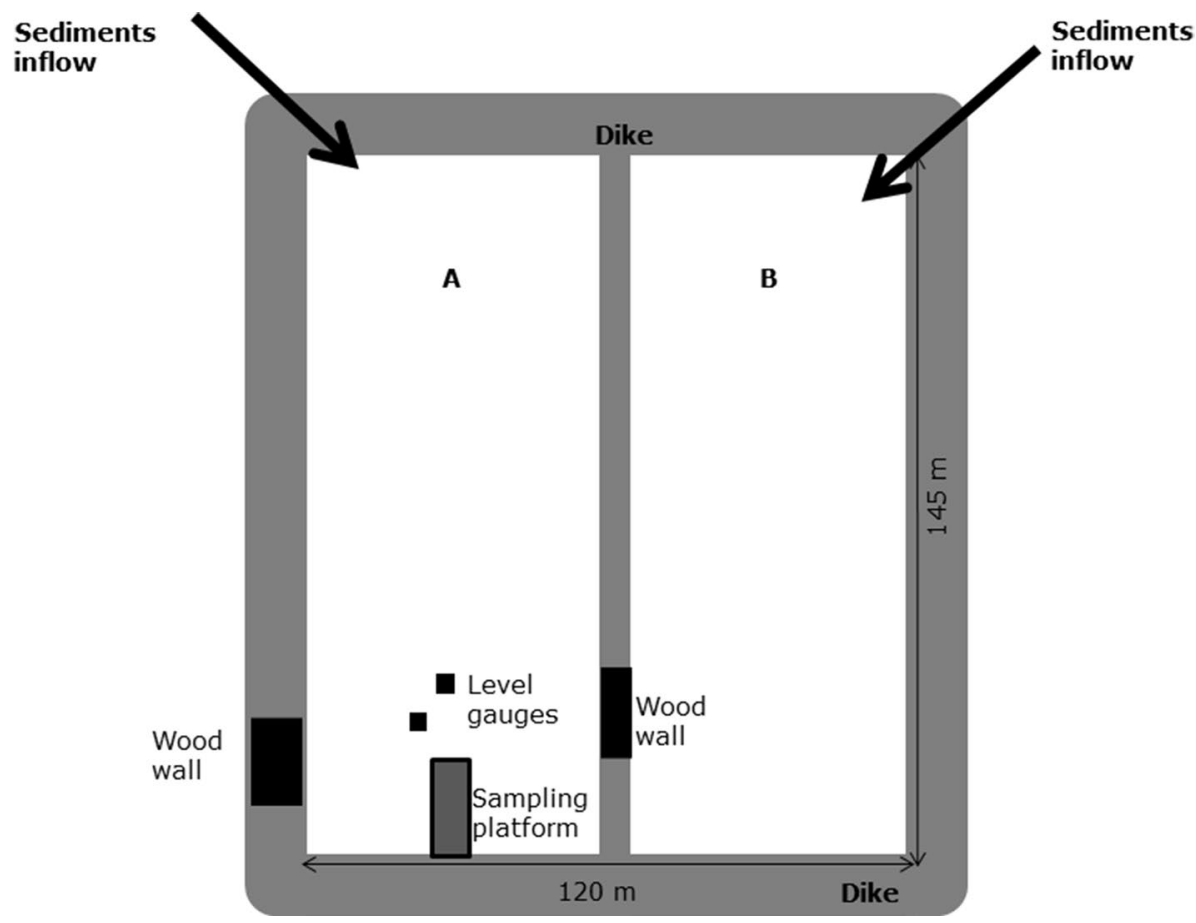

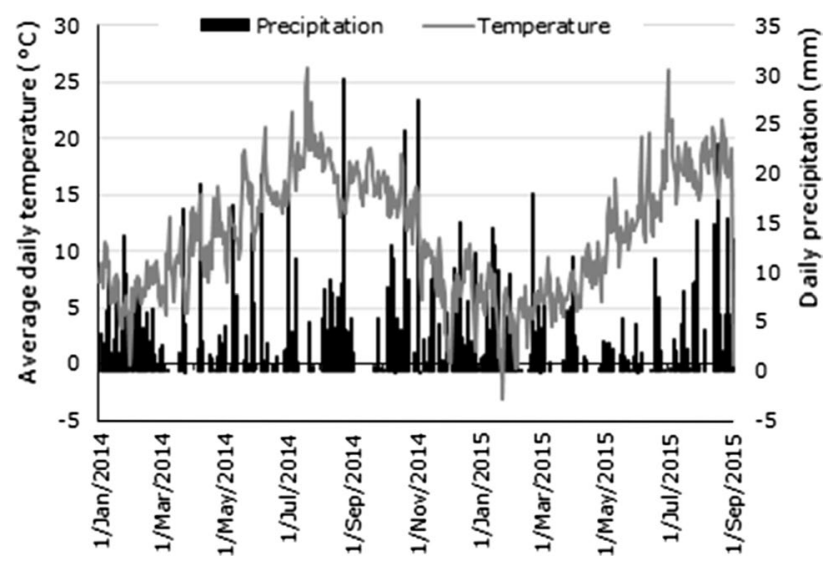

Fig. 2 Average daily temperature $\left({ }^{\circ} \mathrm{C}\right)$ and daily precipitation $(\mathrm{mm})$ recorded at Wijk aan Zee weather station

sections of $10 \mathrm{~cm}$ at the field and stored in airtight jars for further analysis in the laboratory.

\section{Analytical methods}

The subsidence of the sediments and settlement of the underlying soil were determined from the readings of the level gauges.

The water content and organic matter content were calculated from the oven dry weight of the samples $(24 \mathrm{~h}$ at $\left.105^{\circ} \mathrm{C}\right)$ and the loss on ignition $\left(4 \mathrm{~h}\right.$ at $\left.550^{\circ} \mathrm{C}\right)$ of the samples (ISO/TS 17892-1:2014). These two parameters were determined for each $10 \mathrm{~cm}$ section, being $0 \mathrm{~cm}$ the top of the deposit. The water content is represented in $\mathrm{g}_{\text {water }} / \mathrm{g}_{\text {dry matter }}$ (geotechnical water content) since the sediments have more water than dry matter and this representation allows better identification of changes.

The total of N, P and S was determined at the Chemical Biological Soil Laboratory of Wageningen University and Research Centre, The Netherlands. The dredged sediments samples were oven-dried for $24 \mathrm{~h}$ at $105^{\circ} \mathrm{C}$. One sub-sample was digested with the DigiPrep (aquaregia method, according to NEN-69610) and analysed with a Thermo (type iCAP) ICP-AES for $\mathrm{P}$ and $\mathrm{S}$. The other sub-sample was used to analyse total organic $\mathrm{N}$ with a Leco $\mathrm{C} / \mathrm{N}$ analyser. The analysis of $\mathrm{N}, \mathrm{P}$ and $\mathrm{S}$ was done in two batches: column samples 3 and 7-10 were done in the first batch, and column samples 11-12 in the second batch. N, P and S were analysed for each section of $20 \mathrm{~cm}$.

The type of organic matter was characterized with the Rock-Eval $6^{\circledR}$ method, described in (Oliveira et al. 2017). The Rock-Eval ${ }^{\circledR}$ analysis of columns $3-5$ and $7-10$ was done in one batch, and the analysis of columns 11-12 was done in a second batch. The Rock-Eval $6^{\circledR}$ analysis was done for each section of $20 \mathrm{~cm}$.

\section{Results}

A subsidence of $19 \mathrm{~cm}$ was observed from 30/Mar/2014 (end filling stage 1) to 30/Jun/2014 (day before start filling stage 2), and a subsidence of $69 \mathrm{~cm}$ was observed from 9/Oct/2014 (end filling stage 2) to 27/Aug/2015 
Table 1 Sampling dates and parameters analysed

\begin{tabular}{|c|c|c|c|c|c|}
\hline \multirow[t]{2}{*}{ Date } & \multirow[t]{2}{*}{ Action } & \multirow[t]{2}{*}{ Water content } & \multicolumn{2}{|c|}{ Organic matter } & \multirow{2}{*}{$\begin{array}{l}\text { Total } \mathrm{N} \\
\mathrm{P} \text { and } \mathrm{S}\end{array}$} \\
\hline & & & Content & Type & \\
\hline 20/Jan/2014 & Start filling stage 1 & & & & \\
\hline 30/Mar/2014 & Sampling 1 & $\mathrm{Y}$ & $\mathrm{Y}$ & $\mathrm{N}$ & $\mathrm{N}$ \\
\hline 30/Mar/2014 & End filling stage 1 & & & & \\
\hline 8/Apr/2014 & Sampling 2 & $\mathrm{Y}$ & $\mathrm{Y}$ & $\mathrm{N}$ & $\mathrm{N}$ \\
\hline 3/Jun/2014 & Sampling 3 & $\mathrm{Y}$ & $\mathrm{Y}$ & $\mathrm{Y}$ & $\mathrm{Y}$ \\
\hline 1/Jul/2014 & Start filling stage 2 & & & & \\
\hline 1/Jul/2014 & Sampling 4 & $\mathrm{Y}$ & $\mathrm{Y}$ & $\mathrm{Y}$ & $\mathrm{N}$ \\
\hline 8/Sep/2014 & Sampling 5 & $\mathrm{Y}$ & $\mathrm{Y}$ & $\mathrm{Y}$ & $\mathrm{N}$ \\
\hline 9/Oct/2014 & Sampling 6 & $\mathrm{Y}$ & $\mathrm{Y}$ & $\mathrm{N}$ & $\mathrm{N}$ \\
\hline $16 /$ Oct/2014 & End filling stage 2 & & & & \\
\hline 13/Nov/2014 & Sampling 7 & $\mathrm{Y}$ & $\mathrm{Y}$ & $\mathrm{Y}$ & $\mathrm{Y}$ \\
\hline 28/Jan/2015 & Sampling 8 & $\mathrm{Y}$ & $\mathrm{Y}$ & $\mathrm{Y}$ & $\mathrm{Y}$ \\
\hline 26/Mar/2015 & Sampling 9 & $\mathrm{Y}$ & $\mathrm{Y}$ & $\mathrm{Y}$ & $\mathrm{Y}$ \\
\hline 4/Jun/2015 & Sampling 10 & $\mathrm{Y}$ & $\mathrm{Y}$ & $\mathrm{Y}$ & $\mathrm{Y}$ \\
\hline 9/Jul/2015 & Sampling 11 & $\mathrm{Y}$ & $\mathrm{Y}$ & $\mathrm{Y}$ & $\mathrm{Y}$ \\
\hline 27/Aug/2015 & Sampling 12 & $\mathrm{Y}$ & $\mathrm{Y}$ & $\mathrm{Y}$ & $\mathrm{Y}$ \\
\hline
\end{tabular}

Y, measured; N, not measured

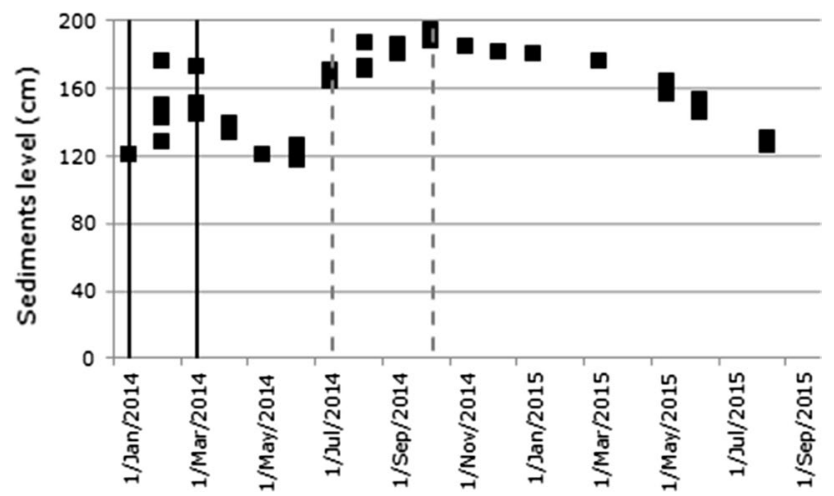

Fig. 3 Sediments level $(\mathrm{cm})$. Black vertical bars correspond to the first filling stage and grey-dashed vertical bars correspond to the second filling stage

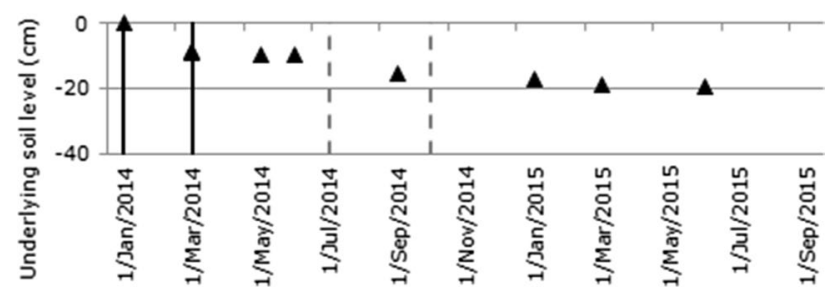

Fig. 4 Level of the underlying soil $(\mathrm{cm})$. Zero corresponds to the level of the underlying soil before the first filling stage. Black vertical bars correspond to the first filling stage and grey-dashed vertical bars correspond to the second filling stage (last measuring date) (Fig. 4). The period from the end of March 2014 to the end of June 2014 had a subsidence of $27 \mathrm{~cm}$ while the equivalent period in 2015 had a subsidence of $31 \mathrm{~cm}$. In addition, the subsidence during the first two months after the first filling stage was $24 \mathrm{~cm}$ (spring) while after the second filling stage was $13 \mathrm{~cm}$ (autumn).

After the first filling stage, the subsidence of the underlying soil (Fig. 4) reached a steady state at $-10 \mathrm{~cm}$. With the second filling stage, the subsidence of the soil underlying the deposit increased to $-19.5 \mathrm{~cm}$.

The water content of the surface layer (Fig. 4) had the highest variation with time but the layers $10-120 \mathrm{~cm}$ followed a similar pattern of variation with time. On 27/ Aug/2015, the water content of Deposit X1 was similar for all depths, with an average of $616 \pm 36 \%$.

The sample taken on 4/Mar/2014 (first sample) had higher water content than all subsequent samples, even than the samples taken during the second filling stage. The increase in water content during the second filling stage was more significant for the top 0-60 cm layers (Fig. 5a) than for the deeper layers (Fig. 5b).

It was observed that most of the plants growing were from the genus Typha. When mature these plants reach a maximum height of $2.5 \mathrm{~m}$, and the roots penetrate to a depth of $40 \mathrm{~cm}$ (http://plants.usda.gov).

The total organic carbon (Fig. 6) did not significantly change throughout the monitoring period. The variation observed in the measurements can be attributed to the 

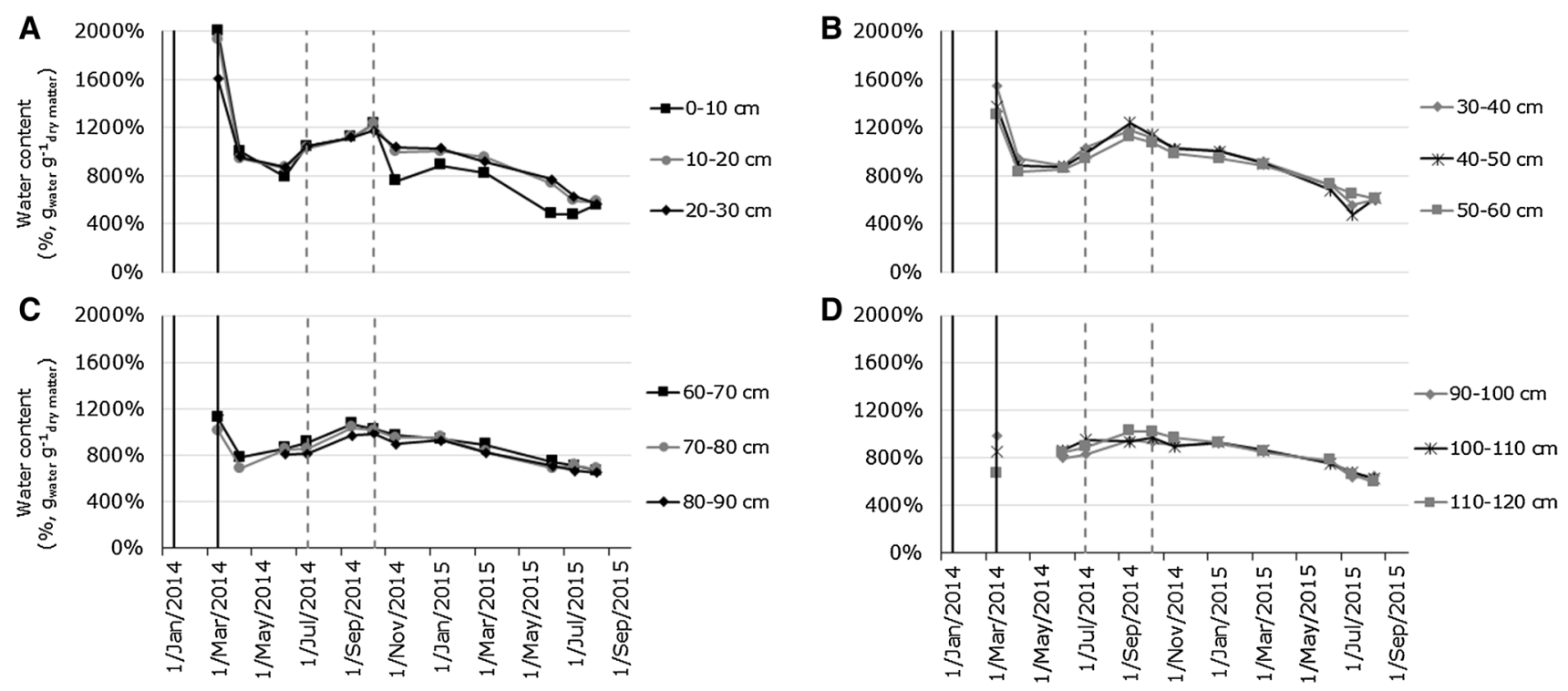

Fig. 5 Water content $\left(\%, \mathrm{~g}_{\text {water }} \mathrm{g}_{\text {dry matter }}^{-1}\right)$ from the surface $(0 \mathrm{~cm})$ to $120 \mathrm{~cm}$ depth. Black vertical bars correspond to the first filling stage and grey vertical bars correspond to the second filling stage

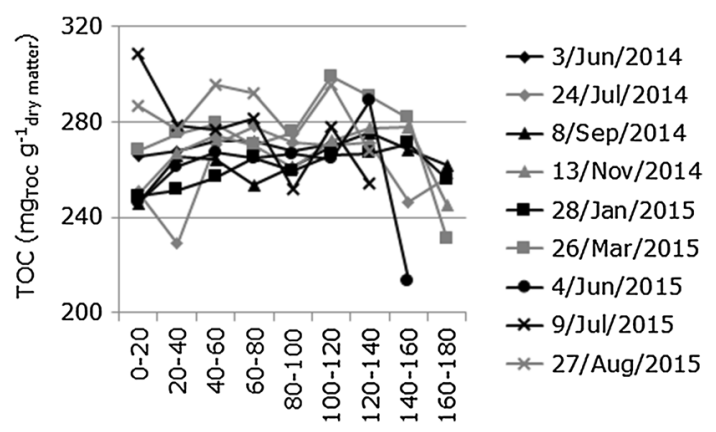

Fig. 6 Total organic carbon $\left(\mathrm{mg}_{\mathrm{TOC}} \mathrm{g}_{\text {dry matter }}^{-1}\right)$

heterogeneity of the Deposit X1. Still, variations in the type of organic matter were observed.

The hydrogen index $(\mathrm{HI})$ and oxygen index $\left(\mathrm{OI}_{\mathrm{RE} 6}\right)$ (Fig. 7) had more fluctuations for the $0-20 \mathrm{~cm}$ layer than for deeper layers. Before the start of the second filling period, the $\mathrm{HI}$ was decreasing and the $\mathrm{OI}_{\mathrm{RE} 6}$ increasing for all depths. The second filling period resulted in higher HI and lower $\mathrm{OI}_{\mathrm{RE} 6}$ up to $60 \mathrm{~cm}$ depth which is related to the addition of freshly dredged sediments on top of the deposit. After the end of the second filling period, the HI decreased and the $\mathrm{OI}_{\mathrm{RE} 6}$ increased slightly until 13/Nov/2014. From 13/Nov/2014 to $4 / \mathrm{Jun} / 2015$, the $\mathrm{OI}_{\mathrm{RE} 6}$ and the HI did not change significantly for the depths $20-120 \mathrm{~cm}$. After 4/ $\mathrm{Jun} / 2015$, the $\mathrm{HI}$ increased and the $\mathrm{OI}_{\mathrm{RE} 6}$ decreased for all depths.
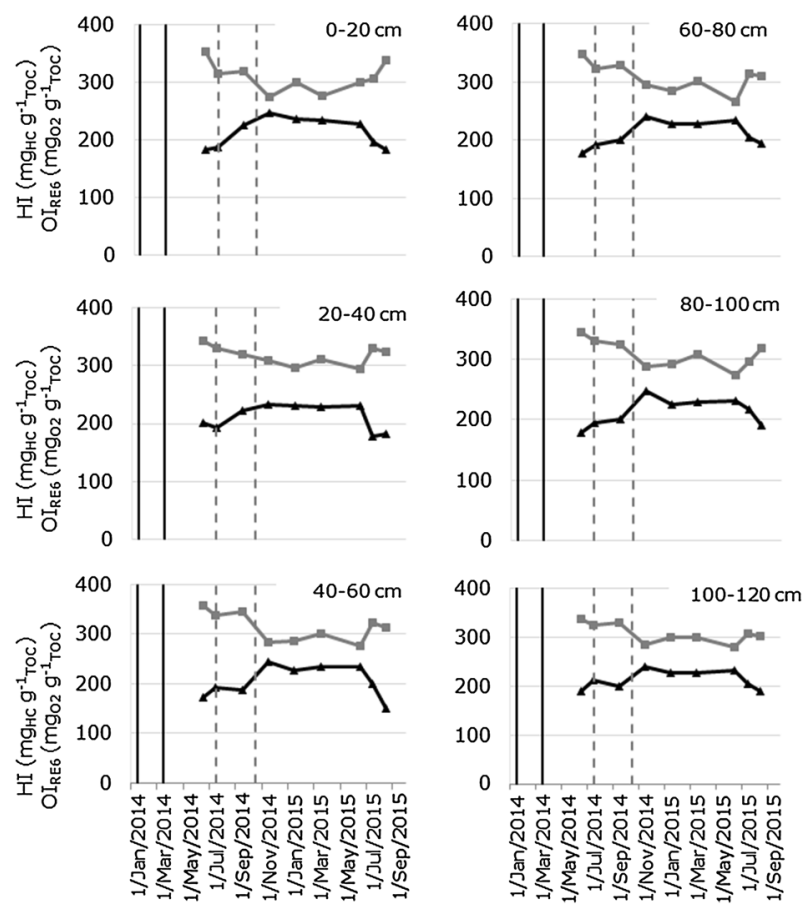

Fig. 7 Hydrogen index (HI) and oxygen index $\left(\mathrm{OI}_{\mathrm{RE} 6}\right)$ for every $20 \mathrm{~cm}$ section. Black vertical bars correspond to the first filling stage and grey vertical bars correspond to the second filling stage

The total of N, P and S is homogeneous with depth, and the changes observed from 3/Jun/2014 to 4/Jun/2015 might be related to the heterogeneity of the Deposit X1. 

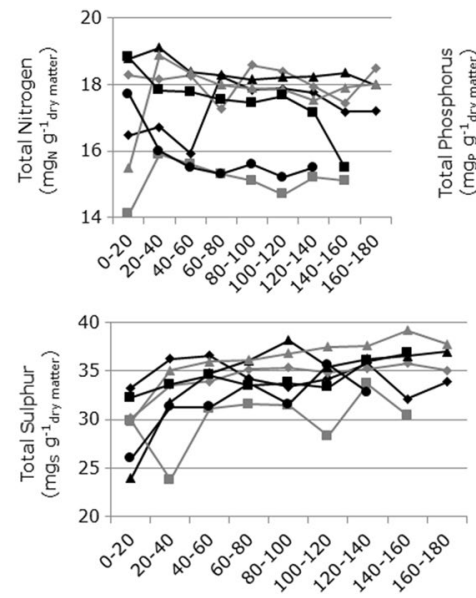

Fig. 8 Total nitrogen $\left(\mathrm{mg}_{\mathrm{N}} \mathrm{g}_{\text {dry }}^{-1}\right.$ matter $)$, total phosphorus $\left(\mathrm{mg}_{\mathrm{P}}\right.$ $\left.\mathrm{g}_{\text {dry matter }}^{-1}\right)$ and total sulphur $\left(\mathrm{mg}_{\mathrm{S}} \mathrm{g}_{\text {dry matter }}^{-1}\right)$

The samples from 9/Jul/2015 to 27/Aug/2015 seem to divert from the previous samples (Fig. 8).

\section{Discussion}

A subsidence of $88 \mathrm{~cm}$ for the sediment and $19.5 \mathrm{~cm}$ for the underlying soil was observed during the 17 months of monitoring of the deposit.

While the period from the end of March 2014 to the end of June 2014 had a subsidence of the sediment of $27 \mathrm{~cm}$, the similar period in $2015 \mathrm{had}$ a subsidence of $31 \mathrm{~cm}$. In addition, the observed subsidence 2 months after the first filling (spring) was $24 \mathrm{~cm}$ while 2 months after the second filling (autumn) was $13 \mathrm{~cm}$. Other authors found that decomposition and humification of the organic matter result in the degradation of the soil structure, a reduction in the soil capacity to store, retain and transmit water, and a higher propensity to shrink with increasing water potentials (Kechavarzi et al. 2010). Ripening of dredged sediments results in the increase of the water potential (Vermeulen 2007), and this can be related to the increase of the subsidence rate with time. In addition, subsidence rates are higher in the warmer months of spring and summer than during the cooler months of autumn and winter. Previous studies have shown that plants have an important role in the hydrology of wetlands (Berglund and Berglund 2011; Oliveira et al. 2018, In Press), and therefore, the higher subsidence in warmer months can be related to evapotranspiration.

After the first filling stage, the subsidence of the underlying soil reached a steady state at $-10 \mathrm{~cm}$. With the second filling stage, the subsidence increased to $-19.5 \mathrm{~cm}$. Since below the deposit anaerobic conditions prevail, the subsidence of the underlying soil is mainly shrinkage due to the overburden pressure, as also reported by (van Asselen 2011).
A characteristic of peatlands is the capacity of changing volume to store water (a phenomenon called mire breathing), and therefore, peatlands can swell and shrink as a response to different water contents (Kellner and Halldin 2002; Price and Schlotzhauer 1999). Therefore, it can be expected that at least part of the subsidence of the underlying soil is reversible if the overburden pressure is removed, and the peat is re-wetted (Gebhardt et al. 2010).

One solution to avoid such high subsidence rates is to spread thin layers of sediments over the field. This solution could also protect higher extensions of peatland from aerobic conditions since the sediments have a high water retention capacity. Laboratory scale experiments with samples of $1,5 \mathrm{~cm}$ height of the same sediments have shown that after 141 days at $20^{\circ} \mathrm{C}$ the organic matter mineralization was negligible, and the samples had enough undrained shear strength to sustain cattle and tractors (Oliveira et al. 2017). The solution of thinner layers would not only limit air penetration due to the high water retention capacity but also allow shallower groundwater tables which is a complementary measure to reduce land subsidence (Dawson et al. 2010; Querner et al. 2012). Still, the cost-effectiveness of spreading the sediments over larger areas must be properly accessed to avoid higher environmental impacts (Bates et al. 2015).

The water content of the top $0-10 \mathrm{~cm}$ layer had the highest variation with time which is initially related to the horizontal removal of water through the adjustable wooden walls and later with the weather conditions and evapotranspiration by plants.

For the layers deeper than $60 \mathrm{~cm}$, no roots were observed during sampling and the water content decreases with depth which is most probably related to the ongoing compaction and shrinkage which can turn the underlying layers impermeable (Dawson et al. 2010) thus limiting dewatering and ripening of the dredged sediments. In addition, the fluctuations in the surface layers are also influenced by the weather conditions and plants growth. The increase in the water content due to the second phase of filling had a delayed effect for deeper layers which can be related to lower hydraulic conductivity caused by the compaction. This delayed response was also observed by Holden and Burt (2002).

Still, on the last sampling date, the water content was similar for all depths indicating that the systems tend to a homogeneous state.

As mentioned before, the researchers chose to characterize the deposit from the top to the bottom. For a more indepth analysis of specific layers in time, an extensive modelling is required to correct the results for the shrinkage rate of each layer. This will be done in a separate study.

The total organic carbon did not significantly change throughout the monitoring period, and the variation observed in the measurements can be attributed to the heterogeneity of the Deposit X1. This is also in line with 
previous observations on lab scale (Oliveira et al. 2017) and meso-scale experiments (Oliveira et al. 2018, In Press) using sediments dredged from the same location.

The hydrogen index (HI) and oxygen index $\left(\mathrm{OI}_{\mathrm{RE}}\right)$ had more fluctuations for the 0-20 cm layer than for deeper layers since this top layer was the more exposed to weather conditions and also to aerobic conditions. Before the start of the second filling period, the HI was decreasing and the $\mathrm{OI}_{\mathrm{RE} 6}$ increasing for all depths, i.e. the changes in the type of organic matter are indicating progressive humification with depth (Albrecht et al. 2015; Disnar et al. 2003). The second filling period resulted in higher $\mathrm{HI}$ and lower $\mathrm{OI}_{\mathrm{RE}}$ up to $60 \mathrm{~cm}$ depth which is related to the addition of freshly dredged sediments on top of the deposit. After the end of the second filling period and until 13/Nov/2014, there was a second period of humification. From 13/Nov/2014 to 4/ $\mathrm{Jun} / 2015$, the $\mathrm{OI}_{\mathrm{RE} 6}$ and the $\mathrm{HI}$ did not change significantly for the depths $20-120 \mathrm{~cm}$. After $4 / \mathrm{Jun} / 2015$, there was a decrease in $\mathrm{OI}_{\mathrm{RE} 6}$ and an increase in $\mathrm{HI}$ which indicated that there was mineralization of the organic matter (Albrecht et al. 2015; Disnar et al. 2003).

Previous studies with the same sediments have shown that the water retention capacity of the sediments dredged from the same location varies from $0.71 \mathrm{~cm}_{\text {water }}^{3} / \mathrm{cm}_{\mathrm{dry} \text { matter }}^{3}$ before ripening to 1.02 after ripening for $\mathrm{a} \mathrm{pF}=2$ (Oliveira et al. 2017), and the high water content can protect the organic matter from mineralization.

On the last sampling date, the decrease in geotechnical water content was still ongoing, and no significant decrease in organic matter content or total organic carbon was observed, even though oxidation changed from humification to mineralization. Some authors' report that initial subsidence in newly drained areas is mainly due to shrinkage and after a certain period oxidation becomes the main cause of subsidence (Hooijer et al. 2012; Pronger et al. 2014).

The total of N, P and $\mathrm{S}$ was homogeneous with depth, and the changes observed from 3/Jun/2014 to 4/Jun/2015 might be related to the heterogeneity of the Deposit X1. The samples from $9 / \mathrm{Jul} / 2015$ to $27 / \mathrm{Aug} / 2015$ seem to divert from the previous samples which might be related to an analytical difference since the last two samples were analysed in a second batch. The nutrients content together with the high organic matter content makes the dredged sediment suitable for crop growing and fertilizer, reinforcing the ideal application on land when contamination levels are not significant (Mattei et al. 2017).

\section{Conclusions}

After 17 months of monitoring an upland deposit of dredged sediments, a total subsidence of $107.5 \mathrm{~cm}$ was observed being $88 \mathrm{~cm}$ attributed to the sediments subsidence and $19.5 \mathrm{~cm}$ to the underlying soil subsidence.
The observed subsidence was due to shrinkage since no significant decrease in organic matter content or total organic carbon was observed. Despite that, there was a period of organic matter humification followed by a period of mineralization of the organic matter.

When the last column sample was taken, shrinkage was still ongoing and, consequently, also subsidence.

The results suggest that spreading thinner layers of sediments could result in less subsidence due to the overburden pressure. Furthermore, this overburden pressure can cause the sediments and underlying soil to be squeezed to the waterways which implies more frequent dredging. Therefore, the alternative of spreading thinner layers of sediments on land should be explored not only for the reasons previously mentioned but also because this alternative can increase the nutrients and organic matter content of a more vast area.

Acknowledgements This research is supported by the Dutch Technology Foundation STW, which is part of the Netherlands Organisation for Scientific Research (NWO), and which is partly funded by the Ministry of Economic Affairs via the perspective program BioGeoCivil (Grant 11344). We would like to express gratitude to Karsten Hopman from Hoogheemraadschap Hollands Noorderkwartier (HHNK) for the vital support with the field experiment and to Roderick Tollenaar for all the support.

Open Access This article is distributed under the terms of the Creative Commons Attribution 4.0 International License (http://creativeco mmons.org/licenses/by/4.0/), which permits unrestricted use, distribution, and reproduction in any medium, provided you give appropriate credit to the original author(s) and the source, provide a link to the Creative Commons license, and indicate if changes were made.

\section{References}

Aich S, McVoy CW, Dreschel TW, Santamaria F (2013) Estimating soil subsidence and carbon loss in the Everglades Agricultural Area, Florida using geospatial techniques. Agric Ecosyst Environ 171:124-133. https://doi.org/10.1016/j.agee.2013.03.017

Albrecht R, Sebag D, Verrecchia E (2015) Organic matter decomposition: bridging the gap between Rock-Eval pyrolysis and chemical characterization (CPMAS 13C NMR). Biogeochemistry 122:101111. https://doi.org/10.1007/s10533-014-0033-8

Bates M, Fox-Lent C, Seymour L, Wender B, Linkov I (2015) Life cycle assessment for dredged sediment placement strategies. Sci Total Environ 511:309-318. https://doi.org/10.1016/j.scito tenv.2014.11.003

Berglund Ö, Berglund K (2011) Influence of water table level and soil properties on emissions of greenhouse gases from cultivated peat soil. Soil Biol Biochem 43:923-931. https://doi.org/10.1016/j. soilbio.2011.01.002

Daily weather data for the Netherlands (2016) KNMI-Koninklijk Nederlands Meteorologisch Instituut, Ministry van Infrastructuur en Milieu (Royal Netherlands Meteorological Institute-Ministry of Infrastructure and the Environment). http://www.sciamachyvalidation.org/climatology/daily_data/selection.cgi. Accessed 26 April 2016 
Dawson Q, Kechavarzi C, Leeds-Harrison PB, Burton RGO (2010) Subsidence and degradation of agricultural peatlands in the Fenlands of Norfolk, UK. Geoderma 154:181-187. https://doi. org/10.1016/j.geoderma.2009.09.017

Disnar JR, Guillet B, Keravis D, Di-Giovanni C, Sebag D (2003) Soil organic matter (SOM) characterization by Rock-Eval pyrolysis: scope and limitations. Org Geochem 34:327-343. https://doi. org/10.1016/S0146-6380(02)00239-5

Gebhardt S, Fleige H, Horn R (2010) Shrinkage processes of a drained riparian peatland with subsidence morphology. J Soils Sediments 10:484-493. https://doi.org/10.1007/s11368-009-0130-9

Holden J, Burt TP (2002) Infiltration, runoff and sediment production in blanket peat catchments: implications of field rainfall simulation experiments. Hydrol Process 16:2537-2557. https://doi. org/10.1002/hyp.1014

Hooijer A, Page S, Jauhiainen J, Lee WA, Lu XX, Idris A, Anshari $\mathrm{G}$ (2012) Subsidence and carbon loss in drained tropical peatlands. Biogeosciences 9:1053-1071. https://doi.org/10.5194/ bg-9-1053-2012

Kechavarzi C, Dawson Q, Leeds-Harrison PB (2010) Physical properties of low-lying agricultural peat soils in England. Geoderma 154:196-202. https://doi.org/10.1016/j.geoderma.2009.08.018

Kellner E, Halldin S (2002) Water budget and surface-layer water storage in a Sphagnum bog in central Sweden. Hydrol Process 16:87-103. https://doi.org/10.1002/hyp.286

Kolker AS, Allison MA, Hameed S (2011) An evaluation of subsidence rates and sea-level variability in the northern Gulf of Mexico. Geophys Res Lett 38:L21404. https://doi.org/10.1029/2011gl0494 58

Linders JA (2011) Baggerplan Wormer- en Jisperwater-Dredging plan for Wormer- en Jisperwater (in Dutch). Hoogheemraadschap Hollands Noorderkwartier

Mattei P, Pastorelli R, Rami G, Mocali S, Giagnoni L, Gonnelli C, Renella G (2017) Evaluation of dredged sediment co-composted with green waste as plant growing media assessed by eco-toxicological tests, plant growth and microbial community structure. J Hazadours Mater 333:144-153. https://doi.org/10.1016/j.scito tenv.2016.05.140

Oleszczuk R, Bohne K, Szatylowicz J, Brandyk T, Gnatowski T (2003) Influence of load on shrinkage behavior of peat soils. J Plant Nutr Soil Sci 166:220-224. https://doi.org/10.1002/jpln.200390032

Oliveira BRF, Smit MPJ, van Paassen LA, Grotenhuis JTC, Rijnaarts HHM (2017) Functional properties of soils formed from biochemical ripening of dredged sediments—subsidence mitigation in delta areas. J Soils Sediments 17(1):286-298. https://doi. org/10.1007/s11368-016-1570-7

Oliveira BRF, Smit MPJ, Rijnaarts HHM, Grotenhuis T (2018) Subsidence of organic dredged sediments-mesoscale experiments with different water levels. J Soils Sediments (In Press)

Price JS, Schlotzhauer SM (1999) Importance of shrinkage and compression in determining water storage changes in peat: the case of a mined peatland. Hydrol Process 13:2591-2601. https://doi. org/10.1002/(SICI)1099-1085(199911)13:16\%3c2591::AIDHYP933\%3e3.0.CO;2-E

Pronger J, Schipper LA, Hill RB, Campbell DI, McLeod M (2014) Subsidence rates of drained agricultural peatlands in New Zealand and the relationship with time since drainage. J Environ Qual. https://doi.org/10.2134/jeq2013.12.0505

Querner EP, Jansen PC, van den Akker JJH, Kwakernaak C (2012) Analysing water level strategies to reduce soil subsidence in Dutch peat meadows. J Hydrol 446-447:59-69. https://doi.org/10.1016/j. jhydrol.2012.04.029

Sanei H, Stasiuk LD, Goodarzi F (2005) Petrological changes occurring in organic matter from recent lacustrine sediments during thermal alteration by Rock-Eval pyrolysis. Org Geochem 36:1190-1203. https://doi.org/10.1016/j.orggeochem.2005.02.009

van Asselen S (2011) The contribution of peat compaction to total basin subsidence: implications for the provision of accommodation space in organic-rich deltas. Basin Res 23:239-255. https:// doi.org/10.1111/j.1365-2117.2010.00482.x

Vermeulen J (2007) Ripening of PAH and TPH polluted sedimentsdetermination and quantification of bioremediation parameters. Wageningen University and Research Centre, Wageningen, The Netherlands

Vermeulen J, Grotenhuis T, Joziasse J, Rulkens W (2003) Ripening of clayey dredged sediments during temporary upland disposal a bioremediation technique. J Soils Sediments 3:49-59. https://doi. org/10.1007/bf02989469

Wöppelmann $\mathrm{G}$ et al (2013) Is land subsidence increasing the exposure to sea level rise in Alexandria, Egypt? Geophys Res Lett 40:2953-2957. https://doi.org/10.1002/grl.50568

Zech W et al (1997) Factors controlling humification and mineralization of soil organic matter in the tropics. Geoderma 79:117-161. https://doi.org/10.1016/S0016-7061(97)00040-2 